Article

\title{
Status Quo of Households' Backyard Food Gardens in South Africa: The "Drivers"
}

\author{
Oladipo Olalekan David *(i) and Wynand Grobler
}

Citation: David, O.O.; Grobler, W. Status Quo of Households' Backyard Food Gardens in South Africa: The "Drivers". Sustainability 2022, 14 , 2674. https://doi.org/10.3390/ su14052674

Academic Editor: Hossein Azadi

Received: 12 November 2021

Accepted: 25 January 2022

Published: 25 February 2022

Publisher's Note: MDPI stays neutral with regard to jurisdictional claims in published maps and institutional affiliations.

Copyright: (c) 2022 by the authors Licensee MDPI, Basel, Switzerland. This article is an open access article distributed under the terms and conditions of the Creative Commons Attribution (CC BY) license (https:/ / creativecommons.org/licenses/by/ $4.0 /)$.
School of Economic Sciences, North-West University, Vaal Triangle Campus, Vanderbijlpark 1900, South Africa; wynand.grobler@nwu.ac.za

* Correspondence: olalekan.david@gmail.com

\begin{abstract}
South Africa is one of the most food-secured countries at the national level but is food insecure at the household level. The disconnect in the food security at the national and at household level in the economy is a result of high food prices that most households cannot afford. One of the strategies of ameliorating food insecurity at the household level is the practice of backyard food gardens. This study identifies farmland size, land tenure system, agriculture-related assistance to households, location of residence of the household, agricultural training offered to households, and monetary grants for households for agriculture purpose as the determinants of households' backyard food gardens in South Africa. The study used descriptive (horizontal bar chart) and inferential (Pearson's chi-square) analyses to evaluate the household-level impacts of farmland size, land tenure system, agriculture-related assistance, location of residence, agricultural training, and monetary grants for agriculture purposes of the backyard food gardens in South Africa. The data for the study were sourced from the Statistics South Africa's General Household Survey for 2019. The findings revealed that farmland size, land tenure system, agriculture-related assistance to households, location of residence of the household, agricultural training offered to households, and monetary grants for households for agriculture purposes are significant to households' backyard food gardens in South Africa. It is clear that agriculture-related assistance is welcomed by the households but the spread across all dwelling locations is limited; therefore, there is need to spread agriculture-related assistance to all dwelling areas in South Africa. This will increase the drive towards food production in South Africa.
\end{abstract}

Keywords: food security; food gardens; household farming; agricultural policy and South Africa

\section{Introduction}

The endemic nature to which hunger, because of poverty, spread across global south countries gave rise to in-depth discourse on food security. Food security aligns with the state of accessibility, availability, and utility of food and healthy living. Apart from that, food security can be regarded as the state whereby people in an economy or community have social, physical, and economic means to acquire enough nutritious and safe food that fulfils their dietary requirements for a healthy life [1].

Globally, food security is adversely affected by several factors, such as climate change, pests and diseases, political instability, among others [2]. Pertaining to climate change, global warming affects rainfall patterns and this often leads to poor rainfall patterns [3]. Poor rainfall patterns can lead to drought, which in turn affects food security. This occurs because low rainfall adversely affects prosperous crop production and ultimately decreases the amount of harvested crops. A low food supply may attract higher prices as demand for food may be high [3]. This will have serious, ruinous effects on the poor as they may not be able to afford food at higher prices. Pests, such as army worms and locusts, destroy crops, thus threatening food security. In Africa, pests have wreaked havoc and serious losses in the agricultural sector were experienced [4]. Political instability or wars often drive farmers 
from their land and this affects crop production [5]. This occurs because once farmers leave their farms, they have less time for crop production, hence causing a decline in food supply which adversely impacts food security.

In Sub-Saharan Africa, key challenges that have affected food security include political instability, pests and diseases, poor governance, and poor financial support for farmers, among other factors [1]. Some of the economies affected by food security issues are Nigeria, Somalia, and Zimbabwe. In a society where food insecurity is prevalent, such an economy can cause devastatingly low malnutrition and a high rate of poverty. Consequently, citizens will lack the energy required to work, as experienced in the horn of Africa in the past. In South Africa, it is evident that an estimated 13.4 million households suffered from inadequate or severely inadequate access to food and approximately 1.6 million households suffered hunger in 2017 [6]. This implies that there is need for a panacea to address food insecurity at the household level. This is of greater cognisance since exposure to such levels of limited or no access to food supplies implies that the economy at large has a mammoth task to fight poverty. In 2018, the South African economy registered an annual population growth rate of $1.4 \%$ [7]. The increase in population is critical, especially if that increase is exposed to food shortages at the household level.

It is challenging for the citizens of most of the global south countries due to persistently high levels of poverty and income inequality. In this climate, most Sub-Saharan African countries fall within this web of global south countries, including South Africa. In these countries, food insecurity is an anathema. In the case of South Africa, the net production (supply-side) of food is favourable but net utility (demand-side) of food is unfavourable. This is because the means (income) to buy the expensive foods are either low or close to zero because of the high level of unemployment [8]. With a low level of employment in this generation, food insecurity becomes a threat to survival since the income to purchase food depends on the transitory (social grants) income of the households [9].

This study sought to examine how food insecurity at the household level in South Africa can be alleviated. The gap between national production and household production of foods is well documented in food agency reports, as the country is a net exporter of food, and yet, is food insecure. This thereby causes food insecurity due to an inability to afford the food produced at the national level because of the poor economic status of the majority of the households in South Africa. If this economic quagmire goes unsolved, further inequalities between the rich and the poor in South Africa could be created. Food insecurity at household levels in South Africa could have been exacerbated by outbreak of diseases, such as the COVID-19, as many households lost their means of livelihood as a result of lockdowns. Some of the effects include loss of jobs due to company closures and increased demand for food over a limited supply, which, to some extent, triggered price hikes in some sectors. All these effects further worsened food insecurity at the household level in South Africa. This is justified by the fact that the workers who were laid off became exposed to food insecurities. Although, in the South African context, the government and other private partners donated food hampers, this system it is unsustainable in the long run. A permanent solution is required to address food insecurity at the household level. In this context, household food gardens can be an alternative and sustainable panacea to address food insecurity aspects at household levels [10]. With these identified gaps, the research questions for this study are: (i) What are the determinants of household food gardens in South Africa? (ii) To what extent do these determinants influence household food gardens in South Africa?

This study addresses the aforementioned research questions by sectionalising this research work into the Sections 2-5.

\section{Literature Review}

This segment presents the literature review. Theoretically, key aspects pertaining to food security are articulated. Apart from that, a discussion on recent studies is carried out as well. 


\subsection{Food Security}

There is no single, universally agreed-upon definition of food security; however, the commonly used definition is provided by the World Bank. Food security is defined as secure access by all people in a community or an economy at all times to enough food for a healthy life [11]. From this definition, there are three key elements that relate to food security. These elements are availability, access, and utilisation. This implies that, at household level, citizens should be guaranteed to get enough food at the right time. However, in reality in South Africa, households are facing food insecurity.

\section{Food Security Levels}

Food security can be viewed at diverse levels. Some of these levels can be from a global context, a regional level, a country level, or at household level.

Food security at the global level can be viewed as the state where world food supplies are sufficient, and the food distribution process is able to meet the needs of the total number of global households [12]. Due to factors including agro-ecological zones, pests and diseases, war, global economies end up importing and exporting in a bid to try and mitigate food insecurity. Food importation or exportation is costly, and this ultimately increases the food price for the end users.

At the national level, food security can be regarded as the total of household and sub-national food security and can be defined as the assured national availability of food to meet current minimum per capita requirements for a certain timeframe [13]. At the national level, food security can be achieved through domestic production or imports. However, imports can be expensive, as the importation costs may be borne by the consumers. This increases food prices, and it threatens food security at national and household levels.

Regional food security can be viewed as the state in which all people in a certain region, for example, Africa, have access to healthy food at appropriate times [14]. Regional challenges, such as pests and diseases, war, climate change, political instability, and poor governance, among other factors threaten, food security. Food security at the household level can be defined as having enough food to ensure a minimum intake for all its members [15]. Food security at the household level can be achieved through backyard gardens (own production) or buying.

\subsection{Empirical Literature}

Ref. [1] examined governance quality, remittances, and their implications for food and nutrition security in Sub-Saharan Africa. Ref. [1] discovered that high population growth rates and inflation adversely affected food security. Apart from that, it was also discovered that remittances played a key role in improving food access of households. However, from these research findings it can be concluded that not every household receives remittances from their families or friends in other economies. This implies that such families are still exposed to food insecurity. Apart from that, in the event of major global challenges, such as the outbreak of COVID-19, the level of remittances may be low. This is because of the number of economies plunged into serious unemployment situations. Such effects are passed on from former breadwinners to the dependants, which imply that although remittances can be useful in meeting food needs for families, they cannot be regarded as a sustainable measure. This is because the loss of work of a breadwinner who used to send some money from another economy will also adversely affect their dependants.

Ref. [8] carried out research on food insecurity in South Africa. The research findings showed that social grants were far from sufficient in solving food insecurity in South Africa as the food prices were high [8]. Apart from that, it was discovered that consumption of wild foods can be instrumental in easing food insecurity at household levels [8]. From these research findings, it is clear that the consumption of wild foods can be more appropriate for those in rural areas or those with access to wild forests. For people residing in the urban areas, their access to wild foods can be limited. This shows that the research does not offer 
an inclusive and holistic approach of how food security can be achieved in South Africa at large, but rather it portrays a limited view in favour of those in rural set ups.

In addition to that, [16] examined the impact of climate change on food security in South Africa. From the research, it was unearthed that global warming, drought, and unemployment were key drivers that influenced food insecurity in South Africa [16]. Apart from that, it was also realised that government intentions in the form of funding and technological innovations would be very helpful in addressing the global warming. This, in turn, can help the agricultural sector to thrive well and produce enough food supplies, thus reducing food insecurity. From this research, it can be concluded that abundant food supply may trigger low prices, ceteris paribus, due to the fundamental laws of demand and supply [17]. However, this research lacks clear guidelines of employment and government funding that can be directed towards the key issues raised. This therefore renders the study as more of a theoretical view, and it lacks the explicit practicality on how household food insecurity can be tackled in South Africa.

Ref. [18] posited that backyard gardens can be helpful in meeting food supply at the household level. Backyard gardens and smallholder farmers have been deemed useful in providing healthy diets by supplementing food supply during crisis [10]. However, achieving household autarky through backyard gardening requires community participation and educational campaigns. This helps ensure that there is enough information disseminated about how to perform backyard gardening.

\section{Conceptual Framework and Methodology}

The conceptual framework guiding this study is embedded in the description of food security by the World Health Organisation (WHO) and the Food and Agriculture Organisation (FAO) in which food security is captured from four dimensional perspectives: food availability, food accessibility, food utility, and food stability. The connectivity between food security and its dimensional components are described in Figure 1.

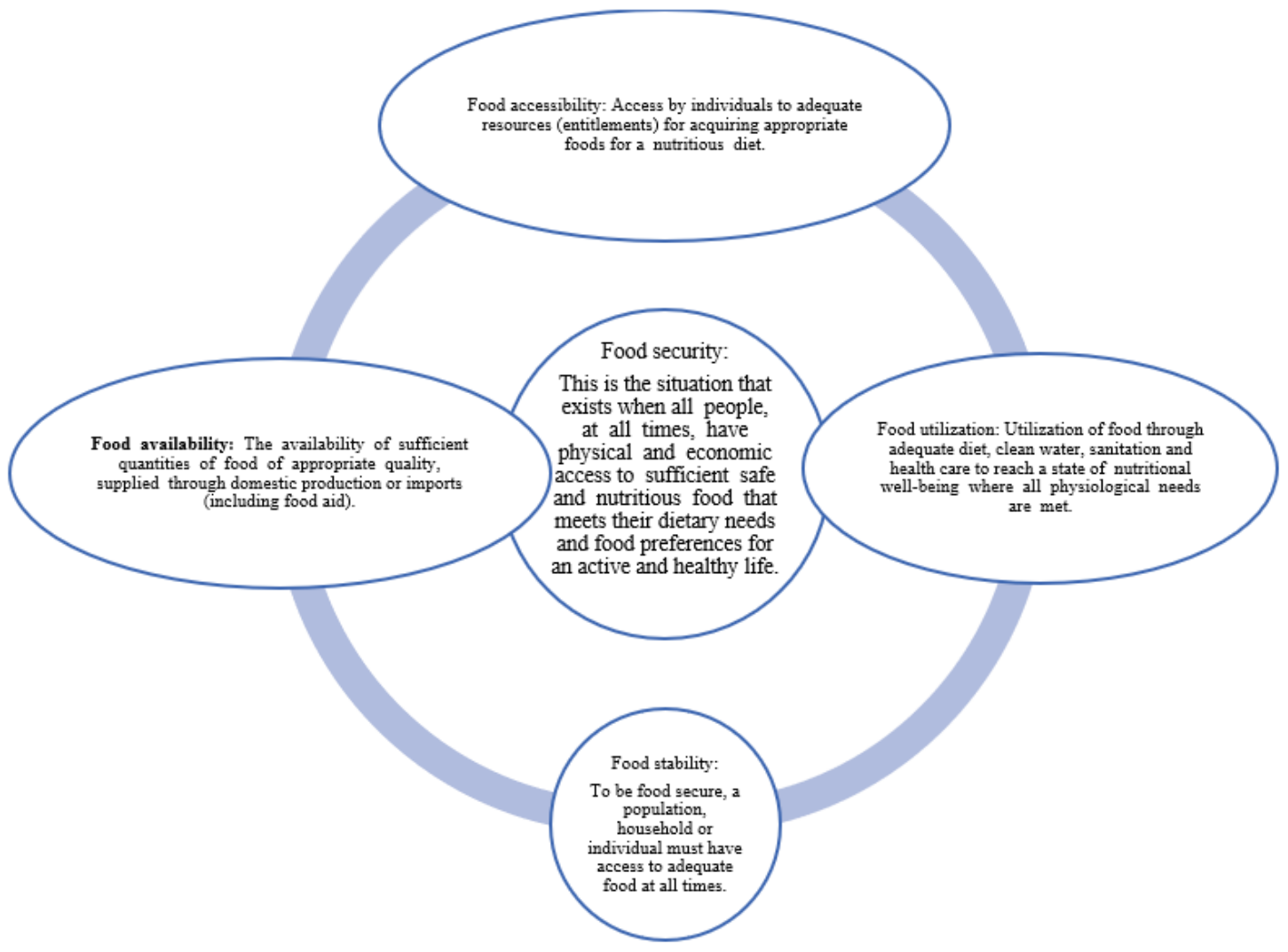

Figure 1. Conceptual framework for food security. Source: Adaptation from WHO/FAO (1996) and diagram designed by Authors (2019). 
These dimensions are streamlined to food availability at the household level in South Africa in the form of small-scale food production and the strategies that will yield productivity in the short term, food security in the medium term and, improved standard of living in the long term. With food availability, other dimensions are possible with policy directions where equilibrium of food supply (food availability) and food demand (food accessibility, food utilization and food stability) is achieved.

This study employed the combined descriptive and inferential analytical approaches in which the status quo of backyard food gardens and its determinants are evaluated with descriptive statistics. The horizontal bar chart forms the analysis rationale for examining the status quo of households' backyard food gardens in South Africa and the cross-tabulation Pearson's chi-square technique is used to complement the horizontal bar chart to draw valid conclusions on the impact of farmland size, land tenure system, agriculture-related assistance to households, location of residence of the household, agricultural training offered to households, and monetary grants for households for agriculture purposes on households' backyard food gardens in South Africa.

\section{Research Design and Estimations}

This study deployed stylised fact analysis to establish the status quo of households' backyard food gardening in South Africa and the cross-tabulation technique (Pearson chisquare) is employed to determine the impacts of determinants of food security (farmland size, land tenure system, agriculture-related assistance, location of residence, training and grant) on backyard food gardening. The study employed the stylised fact analysis because it is simple and reveals the trends economic variables. The Pearson chi-square estimation follows the positive normal distribution approach in which the estimation model is stated:

$$
\chi^{2}=\sum \frac{\left(O_{i}-E_{i}\right)^{2}}{E_{i}}
$$

where $\chi^{2}$ is chi-square, $O_{i}$ is observed value, and $E_{i}$ is expected value.

With cross tabulation technique, the aggregate impact of farmland size, land tenure system, agriculture-related assistance, location of residence, training and grant on backyard food gardening in South Africa is examined.

\section{Data and Analysis}

The data for the study were gathered from the existing data of the 20,908 General Household surveys of 2019, conducted by StatSA. The total number of households in South Africa stands at over 17 million, but due to complexity of studying the entire population, this study resorted to the sample of 20,908, which is large enough for sample representation that valid inferences could be drawn on. Thus, to capture the interactions between backyard food gardens and its determinants (farmland size, land tenure system, agriculture-related assistance to households, location of residence of the household, agricultural training offered to households and monetary grants for households for agriculture purpose) in South Africa, existing data on General Household Survey of 2019 was employed and the data was sourced from Statistics South Africa (StatsSA).

The centrality of this study lies in the capacity of the backyard food gardens of households to combat food insecurity and reduce poverty in South Africa. With household gardens, farming for subsistence food production assists the households, especially those at the bottom of the pyramid in society to meet calorie intake, thereby improving the general standard of living.

In Table 1, the general household survey (GHS) data for 2019 shows that more than $88 \%$ of households are not in the categories for practicing backyard gardens for food production, while less than $12 \%$ of households are applicable to that category. The statistics revealed that $10.3 \%$ of households validate that they are involved in backyard garden practices in South Africa, but $1.1 \%$ of households do not engage in backyard garden practices in South Africa. 
Table 1. Households' backyard food gardens.

\begin{tabular}{cccc}
\hline Values & Categories & Response & Percent \\
\hline 1 & Yes & 2696 & 10.3 \\
2 & No & 278 & 1.1 \\
8 & Not applicable & 17,815 & 87.9 \\
9 & Unspecified & 119 & 0.6 \\
\hline
\end{tabular}

Source: Adaptation from StatSA (2019), extracted and modified by Authors (2021).

Traditionally, land is one of the key factors of production, especially agriculture production where the soil needs to be tilled. Accessibility to land determines the capacity of food gardens that households can maintain in South Africa. GHS data for 2019 shows that $88 \%$ of households do not apply for agricultural land and less than $12 \%$ of households use farmland for farming purposes. The results revealed that about $10 \%$ of households used less than $500 \mathrm{sqm}$ of land for farming while about $2 \%$ of households used more than $500 \mathrm{msq}$ of land for farming, as shown in Table 2. The implication of these results are that few households have access to larger portions of land for food production in South Africa.

Table 2. Households' farmland size used for farming.

\begin{tabular}{cccc}
\hline Values & Categories & Response & Percent \\
\hline 1 & Less than $500 \mathrm{~m}^{2}$ (approximately one soccer filed) & 2581 & 9.9 \\
2 & $500 \mathrm{~m}^{2}$ to $9999 \mathrm{~m}^{2}$ (between one soccer field and & 222 & 0.8 \\
3 & one hectare) & 33 & 0.1 \\
4 & 1 but less than 2 hectares & 25 & 0.1 \\
5 & 2 but less than 5 hectares & 13 & 0.0 \\
6 & 5 but less than 10 hectares & 4 & 0.0 \\
7 & 10 but less than 20 hectares & 25 & 0.1 \\
8 & 20 or more hectares & 10 & 0.0 \\
88 & Do not know & 18,815 & 87.9 \\
99 & Unspecified & 180 & 0.9 \\
\hline
\end{tabular}

Source: Adaptation from StatSA (2019), extracted and modified by Authors (2021).

Table 3 depicts that the accessibility of land for food gardens depends on the legislation guiding land acquisition in South Africa. Having access to cost-effective land motivates household involvement in food gardens. The results reveal that the land tenure system is not applicable to more than $88 \%$ of households since they are not practising food gardens. However, more than $7 \%$ of households own the land used for food gardens in South Africa, and 3\% acquired the land for food gardens through tribal authority in South Africa.

Table 3. Households' land tenure system practise.

\begin{tabular}{cccc}
\hline Values & Categories & Response & Percent \\
\hline 1 & Own Lands & 1864 & 7.3 \\
2 & Rents the land & 42 & 0.2 \\
3 & Sharecropping & 19 & 0.1 \\
4 & Tribal authority & 902 & 3.2 \\
5 & State land & 34 & 0.1 \\
6 & Other & 42 & 0.2 \\
7 & Do not know & 11 & 0.1 \\
88 & Not applicable & 17,815 & 87.9 \\
99 & Unspecified & 179 & 0.9 \\
\hline
\end{tabular}


Agricultural policies and programs are mechanisms put in place by the government and its partners to drive food production in the short run and food security in the long run. These programs usually target the sustainable growth of agricultural produce and reducing food insecurity. The statistics in Table 4 revealed that less than $2 \%$ of households are involved with agriculture-related assistance in South Africa in which the categorical responses are "very useful", "somewhat useful" and "not useful". In this study, $1 \%$ of households found the agriculture-related assistance "very useful", $0.4 \%$ of households found the agriculture-related assistance "somewhat useful" and less than $0.01 \%$ of households found the agriculture-related assistance "not useful". These results confirmed the magnitude of importance of agriculture-related assistance to food gardens in South Africa.

Table 4. Agriculture-related assistance.

\begin{tabular}{cccc}
\hline Values & Categories & Response & Percent \\
\hline 1 & Very useful & 279 & 0.9 \\
2 & Somewhat useful & 103 & 0.4 \\
3 & Not useful & 12 & 0.4 \\
8 & Not applicable & 20,352 & 97.9 \\
9 & Unspecified & 162 & 0.8 \\
\hline
\end{tabular}

Source: Adaptation from StatSA (2019), extracted and modified by Authors (2021).

The area in which a household dwelling is situated matters a lot to farm/small-scale gardens because in most urban areas, access to land for farming is a big issue, especially in South Africa. In rural areas where farming land is abundant, it is expected that households engage more in food gardening than urban areas. The locations are categorised as metro and non-metro in this study, where the metros are the major urban areas in South Africa and if otherwise, they are non-metro. The findings revealed that $45 \%$ of households reside in metros in South Africa while 55\% reside in the non-metro areas in South Africa, as shown in Table 5.

Table 5. Households' location of residence.

\begin{tabular}{cccc}
\hline Values & Categories & Response & Percent \\
\hline 1 & Metro & 7918 & 44.8 \\
2 & Non-Metro & 12,990 & 55.2 \\
\hline
\end{tabular}

Source: Adaptation from StatSA (2019), extracted and modified by Authors (2021).

Human capital is one of the major determinants of production since the optimal use of other factors depends on efficient coordination. The more skills that citizens are endowed with, the better the deployment of other factors of production are, such as land, and capital. In households' agricultural settings, the more knowledgeable and equipped the households are in terms of farming, the more the yields of their gardens.

Table 6 reveals that $15 \%$ of households do not benefit from agricultural training, but $0.2 \%$ of households benefited from the skill transfer assistance program of the government. With access to cost-effective skills acquisition on farming, food gardening becomes easier, and more yielding and beneficial for households.

Table 6. Agricultural related training to households.

\begin{tabular}{cccc}
\hline Values & Categories & Response & Percent \\
\hline 1 & Yes & 54 & 0.2 \\
2 & No & 3784 & 14.5 \\
8 & Not applicable & 16,951 & 84.7 \\
9 & Unspecified & 119 & 0.6 \\
\hline
\end{tabular}

Source: Adaptation from StatSA (2019), extracted and modified by Authors (2021). 
Social interventions can come in the form of subsidies, tax waivers, freebies, or grants that 'cushion' the effect of disequilibrium status that the market may pose to society. In agriculture, grants are usually for farmers or potential farmers to encourage them to continue in the practise. In South Africa, grants for households for farming is provided in the form of money that does not have to be paid back to the government, and only a few households were able to benefit. The benefits of the grant are solely for household farming in South Africa. The results show that less than $0.01 \%$ of the households are benefiting from the government money support intervention for agriculture in South Africa, while $15 \%$ of the households are not beneficiary of government money support for agriculture in South Africa, and this category is not applicable to $85 \%$ of the households as depicted in Table 7 .

Table 7. Agricultural grants for households.

\begin{tabular}{cccc}
\hline Values & Categories & Response & Percent \\
\hline 1 & Yes & 13 & 0.01 \\
2 & No & 3825 & 14.7 \\
8 & Not applicable & 16,951 & 84.7 \\
9 & Unspecified & 119 & 0.6 \\
\hline
\end{tabular}

Source: Adaptation from StatSA (2019), extracted and modified by Authors (2021).

Table 8 presents the results of the cross-tabulation analysis, which evaluates the individual importance of the determinants of backyard food garden practices in South Africa. Pearson's chi-square technique is used to test the scientific significance of farmland size, land tenure system, agriculture-related assistance to households, location of residence of the household, agricultural training offered to households, and monetary grants given to households for agriculture purposes.

Table 8. Cross-tabulation analysis of households' backyard food gardens and its determinants.

\begin{tabular}{|c|c|c|c|}
\hline & \multicolumn{3}{|c|}{ Backyard Food Gardens } \\
\hline & Chi-Square & $p$-Value & Degree of Freedom \\
\hline Farmland size & $36,187.912 * * *$ & 0.000 & 27 \\
\hline Land tenure system & $37,213.519 * * *$ & 0.000 & 24 \\
\hline Agriculture-related assistance & $18,055.764^{* * *}$ & 0.000 & 12 \\
\hline Location of residence & $1295.744^{* * *}$ & 0.000 & 3 \\
\hline Training & $37,184.635 * * *$ & 0.000 & 9 \\
\hline Grant & $37,040.272 * * *$ & 0.000 & 9 \\
\hline
\end{tabular}

The cross-tabulation results revealed that there are 21,225 valid cases for the chi-square estimations at different degrees of freedoms for all the determinants (farmland size, land tenure system, agriculture-related assistance to households, location of residence of the household, agricultural training offered to households and money grant to households for agriculture purposes) of food gardens in South Africa. The empirical results show that farmland size, land tenure system, agriculture-related assistance to households, location of residence of the household, agricultural training offered to households and monetary grants for households for agriculture purposes are statistically significant in relation to backyard food gardens at a $1 \%$ percent significance level in South Africa. From these results, it is clear that the specified determinants (farmland size, land tenure system, agriculture-related assistance to households, location of residence of the household, agricultural training of fered to households and money grant to households for agriculture purposes) of backyard food gardens are drivers that can be used to encourage food production at the microlevel in South Africa. The households' food production for achieving sustainable food security in South Africa can be stimulated with proper coordination of policies on farmland accessibility, agriculture-related assistance to households, such as extension services, location of 
residence of the household (urban-rural drift), agricultural training offered to households, and monetary grants for households for agricultural purpose.

Achieving food security via a household's small-scale farming on one hand, with employment generation in another hand, promoting the standard of living will be the end result in South Africa if backyard food gardens are supported at all levels (municipal, provincial, and national).

\section{Conclusions and Recommendations}

From the empirical results, it is evident that farmland size, land tenure system, agriculture-related assistance, location of residence, training, and grants are statistically significant for backyard food gardens in South Africa, as the $p$-values associated with their chi-square are less than 0.01 , albeit at different degrees of freedom. Small-scale farming is one of the strategies recommended for achieving food security due to its inclusiveness. Households' backyard gardens come in handy because basic food crops are produced in small quantities. This is done by the households for subsistence consumption. With this practise in most of the households, food demand pressure will be reduced. Apart from that, food supply may exceed food demand. Thus, excess food supply may force the price of food downward, ceteris paribus, and some level of food security will be ascertained with the interaction of market forces.

Households' backyard food gardens have a higher tendency of increasing food supply and reducing food insecurity in South Africa. In this study, farmland size, land tenure system, agriculture-related assistance to households, location of residence of the household, agricultural training offered to households, and monetary grants for households for agriculture purposes are determinants of households' backyard food gardens. From the empirical findings of this study, farmland size, land tenure system, agriculture-related assistance to households, location of residence of the household, agricultural training offered to households, and monetary grants for households for agriculture purposes are statistically significant to households' backyard gardens in South Africa; thus the study recommends that:

1. With more households involved in food gardens with their own land, more land is needed to practice. The majority of the households use less than $500 \mathrm{msq}$ for farming, which is comparably insufficient for subsistence farming if the household size is large.

2. Thus, there is need for legislation that will promote households' adequate acquisition of land for food gardens and small-scale farming in South Africa.

3. More training for the households to increase agricultural skills, thereby increasing farm yields and food security in South Africa, should be prioritised.

4. Policy to reduce rural-urban migration by providing enabling environments in rural settings. By doing so, people will be encouraged to reside in non-metros. This will further promote an even distribution of infrastructural development and transform rural dwellings.

5. It is clear that agriculture-related assistance is welcomed by the households but the spread across all dwelling locations is limited; therefore, there is a need to spread the agriculture-related assistance to all dwelling areas in South Africa, which will increase the drive of food production in South Africa.

Author Contributions: Conceptualization, O.O.D. and W.G.; methodology, O.O.D.; software, O.O.D. and W.G.; validation, O.O.D. and W.G.; formal analysis, O.O.D. and W.G.; investigation, O.O.D.; resources, O.O.D. and W.G.; data curation, O.O.D..; writing-original draft preparation, O.O.D.; writing-review and editing, O.O.D. and W.G.; visualization, O.O.D.; supervision, W.G.. All authors have read and agreed to the published version of the manuscript.

Funding: This research received no external funding.

Institutional Review Board Statement: Not applicable.

Informed Consent Statement: Not applicable. 


\begin{abstract}
Acknowledgments: This research has been executed by the TRADE research entity, North-West University, as community research to inform policy on food insecurity in South Africa. We are grateful to Statistics South Africa (StatsSA) for providing us access to the data used for this study.
\end{abstract}

Conflicts of Interest: The authors declare that they have no known competing financial interests or personal relationships that could have influenced the work reported in this paper.

\title{
References
}

1. Ogunniyi, A.I.; Mavrotas, G.; Olagunju, K.O.; Fadare, O.; Adedoyin, R. Governance quality, remittances and their implications for food and nutrition security in Sub-Saharan Africa. World Dev. 2019, 127, 104752. [CrossRef]

2. Abdullah; Zhou, D.; Shah, T.; Ali, S.; Ahmad, W.; Din, I.U.; Ilyas, A. Factors affecting household food security in rural northern hinterland of Pakistan. J. Saudi Soc. Agric. Sci. 2019, 18, 201-210. [CrossRef]

3. Leisner, C.P. Review: Climate change impacts on food security- focus on perennial cropping systems and nutritional value. Plant Sci. 2020, 293, 110412. [CrossRef] [PubMed]

4. Mutanga, O.; Dube, T.; Galal, O. Remote sensing of crop health for food security in Africa: Potentials and constraints. Remote Sens. Appl. Soc. Environ. 2017, 8, 231-239. [CrossRef]

5. Mathieu-Comtois, S. Toward Economic Recovery and Food Security in Post-Daesh Iraq: A Framework for Governance Moving Forward. Available online: http:/ / auis.edu.krd/iris/latest-iris-publications/toward-economic-recovery-and-food-security-postdaesh-iraq-framework (accessed on 10 November 2021).

6. Statistics South Africa. Towards Measuring Food Security in South Africa: An Examination of Hunger and Food Inadequacy. 2019. Available online: www.statssa.gov.za (accessed on 10 November 2021).

7. Chakona, G.; Shackleton, C.M. Food insecurity in South Africa: To what extent can social grants and consumption of wild foods eradicate hunger? World Dev. Perspect. 2019, 13, 87-94. [CrossRef]

8. David, O.O.; Grobler, W. Agricultural Production in South Africa: Information and Communication Technology (ICT) Spillover. Int. J. Ebusiness Egovernment Stud. 2019, 11, 167-190. [CrossRef]

9. David, O.O.; Grobler, W. Age progression, social interventions and food insecurity in South Africa: Logistic regression analysis. Int. J. Soc. Sci. Humanit. Stud. 2020, 12, 1309-8063.

10. Fanzo, J. From big to small: The significance of smallholder farms in the global food system. Lancet Planet. Health 2017, 1, e15-e16. [CrossRef]

11. Stevens, C.; Greenhill, R.; Kenman, J.; Devereux, S. The WTO Agreement on Agriculture and Food Security. Institute of Development Studies: Brighton, UK, 2000.

12. Enciso, S.R.A.; Fellmann, T.; Dominguez, I.P.; Santini, F. Abolishing biofuel policies: Possible impacts on agricultural price levels, price variability and global food security. Food Policy 2016, 61, 9-26. [CrossRef]

13. Mohammadpour, P.; Mahjabin, T.; Fernandez, J.; Grady, C. From national indices to regional action-An Analysis of food, energy, water security in Ecuador, Bolivia, and Peru. Environ. Sci. Policy 2019, 101, 291-301. [CrossRef]

14. Molnar, G.; Godefroy, S.B. Review of mechanisms for food safety-related SPS measures within African regional Economic Communities (RECs): Paving the way for a continent-wide food safety coordination effort. Food Control. 2020, 115, 107206. [CrossRef]

15. Brück, T.; D'Errico, M.; Pietrelli, R. The effects of violent conflict on household resilience and food security: Evidence from the 2014 Gaza conflict. World Dev. 2019, 119, 203-223. [CrossRef]

16. Masipa, T.S. The impact of climate change on food security in South Africa: Current realities and challenges ahead. Jamba J. Disaster Risk Stud. 2017, 9, 1-7. [CrossRef] [PubMed]

17. Fanzo, J.; Haddad, L.; McLaren, R.; Marshall, Q.; Davis, C.; Herforth, A.; Jones, A.; Beal, T.; Tschirley, D.; Bellows, A.; et al. The Food Systems Dashboard is a new tool to inform better food policy. Nat. Food 2020, 1, 243-246. [CrossRef]

18. Burgin, S. 'Back to the Future'? Urban Backyards and Food Self-Sufficiency. Land Use Policy 2018, 778, 29-35. Available online: https://www.sciencedirect.com/science/article/abs/pii/S0264837716305415 (accessed on 10 November 2021). 